This is the accepted manuscript. The published version is available as: Marko Ampuja (2019) Four M oments of International Communication Research in the Cold War and Beyond, Javnost - The Public, DOI:

$10.1080 / 13183222.2019 .1633603$

\title{
FOUR MOMENTS OF INTERNATIONAL COM MUNICATION RESEARCH IN THE COLD WAR AND BEYOND
}

\section{Marko Ampuja (Tampere University)}

Abstract:

This article discusses the impact of the Cold War and its legacy on international communication research. Critically reconstructing the history of the Cold War in political-ideological terms, it demonstrates that this research area has been characterised by a battle between liberal internationalist theories and theories of imperialism, which has occurred in two stages. During the Cold War, Western liberal notions of modernisation were challenged by theories of media-cultural imperialism. The end of the Cold War led to a return of liberal notions in international communication research - though they appeared in a less Western-centric form - in association with globalisation theory. The article argues that with the demise of the post-Cold War globalisation zeitgeist and the return of major geopolitical conflicts, theories of "new imperialism", which focus on the interplay between "capitalist" and "territorial" imperialism, offer a fruitful foundation for understanding the early twenty-first century international media and communication order.

KEYW ORDS Cold War; international communication research; modernisation; media imperialism; globalisation; new imperialism

Introduction

Following the end of the Cold War, in the 1990s and early 2000s, many commentators representing a wide political spectrum converged in proclaiming the coming of a more unified world that would mark the end of geopolitical conflicts in general. Fukuyama (1992) expressed the post-1989 capitalist triumphalism among Western political elites by claiming that history had come to an end as a result of the almost universal acceptance of liberal democracy and the free market. For those advocating a globalised form of social democracy, the same moment pointed to the strengthening of a multi-layered system of "global governance" (Held 2002). From a more radical left-wing position, Hardt and Negri (2000) argued that the age of imperialism was over. In its place, they envisioned the emergence of "Empire", "a decentred and deterritorialised apparatus of power that progressively incorporates the entire global realm within its open, expanding frontiers" (ibid., xii) and is pregnant with creative political expressions of global solidarity beyond the nation state.

Even the events of September 11, 2001 did not dispel such post-Cold War globalisation optimism. However, in the new historical conjuncture marked by the global financial crisis, Brexit, Trump's presidential election victory and the rise of right-wing populism across Europe, there is much less confidence in the prospect of benign global governance replacing national sovereignty. Recent world events have shown that powerful demonstrations of national 
interest and geopolitical struggles are far from over, prompting discussions of a "new Cold War" in the form of renewed geopolitical East-West confrontations (e.g., Klare 2018; L. Freedman 2018).

The resurgence of such rhetoric makes it timely to ask questions about the intellectual and ideological dimensions of the Cold War, including how it has shaped and continues to shape international communication research, the developments of which are intermixed with the history of the Cold War and its legacy (Sparks 2007, 111). In this article, I will examine these developments through four defining moments: i) the domination of post-war modernisation theory, ii) the challenge of media-cultural imperialism theory, iii) the rise of globalisation theory and iv) the break-up of globalisation optimism, which defines the current period.

As a starting point, I will argue that making sense of the history of international communication research requires a critical reconstruction of what kind of conflict the Cold War was in political, economic and ideological terms. I will further argue that the paradigm changes and battles in international communication research occurring during and after the Cold War period are structured around one element in particular: a liberal understanding of democracy, markets and individual rights. This underlies the disagreement between modernisation theorists and critical political economists, and it is also a key point of contention between globalisation theorists and their challengers subsequent to the end of the Cold War. Today, this issue remains topical due to the ongoing crisis of liberal democracy and to the increasing power of democratically unaccountable market institutions (e.g., Mair 2013). This crisis has brought forth the serious limitations of liberal internationalism - understood as a conception of international progress as dependant on the global spread of capitalism and the promotion of so-called freemarket principles - as it is severing the links between capitalism and democracy in ways not seen since the end of the Second W orld War. While the current context of the international communication landscape has changed in ways that undermine an analytical recourse to Cold War categories, I will conclude this article with the argument that theories of imperialism, when properly modified in light of political, economic and technological transformations, offer important insights for making sense of the contemporary international media and communication order.

\section{The Emergence of International Communication Research as a Cold War Construct}

The emergence of communication research as a distinctive institutional discipline in the United States occurred in tandem with the beginning of the Cold War in the late 1940s. This confluence was not coincidental, because "communication research became a central pillar in what came to be known as 'modernisation theory' and a part of the Cold War offensive against communism" (Cmiel 1996, 96). The United States emerged from the Second World War as the world's leading geopolitical power, confident in its political, economic and moral superiority. By the early 1950s, social sciences became strongly tied to the US national security goals, particularly the Truman doctrine, according to which the US had the responsibility to act as the leader of the "free world" and "contain" the threat posed by the Soviet Union and communism everywhere. Such goals necessitated massive material and human investments in the development of military forces, together with investments in strategic research that supported an expansionist foreign policy. As a result, the overwhelming majority of US federal funding for the social sciences, including communication research, was drawn from the military and national security agencies during the early 1950s (Simpson 1994, 52-53).

Even with such backers, the mainstream US social scientists did not consider themselves to be advocates of military-imperial power. The Cold War shaped their views of 
themselves as "the guardian class of liberal democracy" (Latham 2000, 22). With the onset of the Korean War especially, the main front of the Cold War shifted from Europe to post-colonial countries in Asia, the M iddle East, Africa and Latin America. The US policy establishment and the intellectuals serving them were concerned that decolonisation would lead to "instability" in the affected countries, leading to social revolutions instead of opening a steady path towards Western-style modernity. This led to widespread interest in processes of "development" and "modernisation", which became the unifying themes of social and communication research in the 1950s and 1960s.

M odernisation theory was a social scientific theory of global transformation that aimed to explain the shift from traditional to modern societies. Its representatives argued that the US and other advanced capitalist countries offered the most rationally organised social model for developing countries. For modernisation theorists such as Daniel Bell and Seymor M artin Lipset, the problem with these countries was that they were negatively affected by the political passions aroused by "irresponsible" third-world politicians and intellectuals who were, in turn, influenced by the "fervent leftism of communist or socialist sort" (Gilman 2003, 60). M odernisation theorists assumed that with the proper methods of an allegedly value-free empirical social science, these waves of misguided passion could be channelled and controlled.

The search for such methods led modernisation theorists to emphasise a set of mental characteristics that would secure a transition from tradition to modernity. Accordingly, they identified two mental structures. The traditional mindset preferred stability, trust in traditional authority figures and an orientation towards the past. Opposing it was the modern "mobile personality", which was interested in new experiences, self-advancement, hard work, science, independent political will formation and civic participation, together with a willingness to keep up with the news, especially international news (Gilman 2003, 96; Sparks 2007, 22). Daniel Lerner, a seminal modernisation theorist, argued that such traits constituted "the most fundamental human factor that must be comprehended by all who plan rapid social change" (Lerner 1958, 46), and he singled out the media as a crucially important "mobility multiplier" capable of cultivating the mobile personality.

The prominent positive role given to the media reflected important conceptual changes in how communication was understood in the US academia during the first decades of the Cold War. Before and during the Second World War, Lerner's teacher, Harold Lasswell, pioneered the study of propaganda. However, in tune with the liberal-democratic rhetoric of the modernisation theory, communication researchers saw propaganda as an anachronous concept in the Cold War context: it spread civic cynicism in times when the question of "how communication might build loyalty at home and stable, new, non-communist nations around the globe became critically important" (Cmiel 1996, 95). Due to its crude connotations, "propaganda" thus gave way to the concepts of communication and persuasion. Following this, Lerner $(1969,182)$ envisioned a "transition from imperialism to international development", seeing "the persuasive transmission of enlightenment [as] the modern paradigm of international communication".

In actuality, however, the modernisation theory constituted a "paradigm of dominance" (Simpson 1994, 62). Simpson (ibid.) points out (pace Sparks 2007, 35) that the key academic journals on communication research focused on how the media "could be used by elites to manage social change", which reduced the majority of early Cold War international communication studies "to simple models based on the dynamics of transmission of persuasive and, in the final analysis, coercive - messages". Even Lerner's benevolent-sounding formulations regarding media-based development were intimately connected to the US psychological warfare operations, such as Benjamin Ringer's and David Sills's 1952 study entitled "Political Extremists in 
Iran". This study provided data on opinion trends in a country that was undergoing a CIAsponsored coup d'état to remove the national government of M ohammed M ossadegh (Simpson 1994, 70), whom Lerner called a classic "propagandist-agitator" (Popp 2008, 84).

Such features of international communication research expressed the conventional US and Western European image of the Cold War, according to which it was a confrontation between two superpowers and mainly caused by the military and political aggression of the Soviet Union (Chomsky 1992, 9-33). This view was presented in a famous US Cold War document, the National Security Council (NSC) Report 68 from 1950. It declared that "the cold war is in fact a real war in which the survival of the free world is at stake" and that "the fundamental design of the Kremlin" was "the complete subversion or forcible destruction of the machinery of government and structure of society" throughout the world.

As with any good ideological construct, the black-and-white narrative of the NSC 68 report was partially based on reality. The Soviet Union was a military imperial power: it sent tanks to East Berlin, Budapest and Prague and later invaded Afghanistan. However, from a critical realist viewpoint, the focus on this issue is not sufficient. The Cold War was, for the Soviet side, primarily a matter of dominating its own satellites, while for the US it was mainly a struggle against the developing countries, insofar as they sought independent paths towards national state-led modernisation. The US did not support brutal dictatorships in the developing countries for the fun of it, but because by backing these dictatorships, it could prevent such countries from taking their own national economic resources into their own hands and thus deny the US corporations' access to such resources. Vital American economic interests were at stake, rather than the alleged M oscow design for world domination. This was also why the modernisation theorists tended to reduce independent nationalism in the Third World to little more than infantile ideological fanaticism (Gilman 2003, 58).

Such features were not limited to the American post-war modernisation research. They expressed the very core of the liberal understanding of democracy. With the development of capitalist economic and social relations from the end of the eighteenth century onwards, the liberal democracies created an institutional separation between the "economic" and "political" spheres (Wood 2012). This institutional separation often leads, especially when forces on the left are weak, to projects that aim to "liberate" the economy from political interventions to as great a degree as possible. Additionally, the liberal definition of democracy even allows for the curtailment of democratic rights "if that is what is needed to protect property and the market against democratic power" (ibid., 203). These fundamental liberal principles were clearly visible in mainstream international communication research during the 1950s and 1960s. Such research was concerned with the study and legitimation of the "right" kinds of development - those that advanced the economic and geopolitical goals of the United States - and prevented development in non-capitalist terms. In this vein, the emphasis that the modernisation theorists placed on media-assisted mental changes sprang from the assumption that the achievement of modernity required an injection of the capitalist spirit to otherwise inert third-world populations (Gilman 2003, 92), with the help of US-style commercial media and consumer culture.

Due to these emphases, international communication research, in its first stage, was founded on a liberal conception of democracy associated with the promotion of negative freedoms, such as the right to exercise individual autonomy from the state, the right to freedom of speech and the right to own property. In contrast, positive freedoms, in particular the right to achieve social and economic equality and the right of the masses in the decolonised countries to choose the forms by which they would be governed, were de-emphasised. In the reality of the US Cold War policies, the promotion of negative freedoms was often limited to the promotion of the 
so-called free markets, instead of democracy and human rights. Understandably, such policies did not go unchallenged.

Challenge from the Core and the Periphery: M edia-Cultural Imperialism and NWICO

Several Cold War events weakened the credibility of modernisation theory, such as the US armed interventions in Vietnam and other countries. National liberation movements sprang up across Latin America, Asia and Africa. Combined with the rise of civil rights movements and student radicalism in the United States, they provided a receptive intellectual atmosphere for research that "had begun to question both the domestic and international foundations of the dominant communication paradigm" (Schiller 2000, 118).

The most serious intellectual and political challenge to the dominant paradigm came from the so-called dependency theorists. According to Frank (1969), the relations between the West and the post-colonial countries were not characterised by assistance and development but by exploitation and inequality. Development under such conditions did not lead to social progress but to patterns of neo-colonial domination that forced "peripheral" nations onto the path of "dependent development" or, even worse, "a development of underdevelopment". From this perspective, development and underdevelopment were actually two sides of the same coin. Both pointed towards a process through which the advanced capitalist countries and their ruling classes extracted surpluses from the developing countries, thus keeping them dependent.

Underdevelopment was not a transitional stage that would be supplanted by advanced capitalism; instead, it was "a condition that plagues regions involved in the international capitalist economy in which they permanently occupy a subordinate position" (Weeks 2012, 97).

Dependency views were closely linked to radical US political economy tradition and theories of monopoly capitalism proposed by Paul Baran and Paul Sweezy. They were interested in updating early $M$ arxist theories of imperialism (by Lenin, Luxemburg and Hilferding) during the post-war period. Instead of direct territorial control and plunder, post-war imperialism was based on neo-colonial patterns of domination and the "parasitic" interests of the core countries. Thus, the peripheral countries' economic activities "were geared to the requirements of foreign capital and the markets of the advanced capitalist countries more than to their own internal needs" (Bellamy Foster 2007). Baran and Sweezy, together with Frank, concluded from this that peripheral nations could achieve growth and development only outside the Western-dominated capitalist system via "the establishment of a socialist planned economy" (Baran 1957, 261). This idea, more than any other, contradicted the affirmative presuppositions of the modernisation theory.

American political economy inspired a host of media researchers, especially in North America, Western Europe and Latin America, to connect such critiques to the analysis of international communication. These studies became associated with the concepts of cultural and media imperialism (e.g., Schiller 1976; Boyd-Barrett 1977). M ost of this early media imperialism research was focused on the United States. Herbert Schiller argued that, contrary to the liberal commentators, the demise of the Western European colonial system did not mean the death of imperialism. The US attempt to rule the world through the power of its media represented a new turn in imperialist domination, and this necessitated a critical focus on "the American international cultural offensive" (Schiller 1969, 15-16).

During its heyday in the 1970s and early 1980s, the classical cultural or media imperialism paradigm emphasised the division of the world into dominating core countries and dominated peripheral countries. The core countries pressured the peripheral countries to model 
their media and communication structures in ways that benefitted the former. This resulted in the non-reciprocity of flows of media products between the North and the South and posed a threat to the survival of the indigenous cultures of the peripheral nations (Ampuja 2013, 80). Such assumptions were backed by a range of studies and statistics showing imbalances in the distribution patterns of international trade in television programmes, film and other media products and the global spread of US media corporations, media equipment and media management practices.

The most important aspect of media-cultural imperialism was the commercialisation of media systems throughout the world. Due to the market power of US media corporations and the political pressure maintained by the US government to liberalise international communication, the American advertising-based media model was exported all over the world. Instead of the "Americanisation" of culture, however, the main problem lay in the commercialisation of public speech, both in the core and in the periphery - a process that has benefitted transnational capital as a whole (Schiller 1969, 99; Schiller 1991, 13).

Nonetheless, transnational power in global communication has tended to serve Western visions of liberal internationalism. Said (1994, 374-375) noted that political conflicts in the Middle East, for example, tend to be discussed within "the categories and images of 'terrorism' and 'fundamentalism', which derive entirely from the concerns and intellectual factories in metropolitan centres like Washington and London". Similar critical perceptions motivated calls for a New World Information and Communication Order (NWICO) by countries belonging to the Non-Aligned M ovement in the 1970s within the UNESCO. Its member states campaigned against the political, military, economic and cultural-ideological hegemony of major powers. As an example of the latter, Western international news organisations influenced politics in various smaller countries by promoting governments that were allied with the United States and de-legitimising those who challenged the status quo (Alleyne 1995, 60). The establishment of the Press Agencies Pool of the Non-Aligned countries in 1976 and the International Commission for the Study of Communication Problems in 1977, which led to proposals for a more balanced international communication order, were attempts to counter such hegemony.

These critical impulses soon collided with Cold War politics and US national interests. No other issue in UNESCO was seen as more dangerous by the US foreign policy elites than the NWICO initiative. The American media reacted to it with outrage and biased reporting (Preston 1989, 123), soon after which the US withdrew from the organisation in 1984 (rejoining in 2003 only), followed by the UK and Singapore. In the Western liberal policy frame, NWICO attacked the "unquestioned, common-sense assumptions" (ibid.) that freedom of the media and human liberty were inseparable from the capitalist marketplace.

The fact that NWICO faced such massive obstacles showed the limits of critical political-economic analysis of communication and associated policy programs during the Cold War. The success of media imperialism theory was always precarious due to its systemic critique of structural economic power, which drew strong counter-reactions from the established elites. The erosion of media-cultural imperialist paradigm in the 1980s was accelerated by the downfall of the Soviet bloc, which eroded the popularity of Marxist-inspired studies of imperialism. The paradigm also had internal deficiencies, particularly due to its incapability to criticise the media practices and the suppressions of the freedom of speech in state socialist countries (Sparks 2007, 112-115). Besides such political defects, it contained analytical weaknesses that invited critiques from international communication researchers of different schools. In the 1980s and 1990s, such critiques emphasised two points. First, it became evident in the 1990s, at the latest, that "new patterns" or "contra-flows" had emerged in global television traffic (Sinclair, Jacka and 
Cunningham 1996), making it less of a "one-way street" (Nordenstreng \& Varis 1974). Second, another major critique of media-cultural imperialism research pointed to its conception of media reception. Boyd-Barrett $(1998,168)$ wrote that the critics were right in arguing against the "simple correlation between colonisation of communication space and the attitudes, beliefs and behaviours of audiences". Even if peripheral audiences mainly consume Western media products, which is by no means certain, they still reinterpret those products on the basis of their own cultural understandings, which undermines the claim that the developing world is being culturally "invaded" from the outside.

These were standard criticisms made by culturally oriented researchers, especially around the turn of the millennium (Ampuja 2013, 98ff), and they are valid on their own terms. What they typically failed to take into account is that the arguments about media or cultural imperialism were never only about cultural power. Critical political economists of the media were interested in the broad social context in which cultural practices took place. Reviewing media imperialism arguments in the context of Asia, Chadha and Kavoori (2000) note that the region's media developments, national gate-keeping policies and audience preferences all counteract the proliferation of Western media. Nonetheless, they point out that the region's media systems were adopting a "US-styled commercialized model of broadcasting", which contributed "little to the creation of a meaningful public sphere" (ibid., 429; see also Chadha $\&$ Kavoori 2015). This was, indeed, a key point made by Schiller in his early works.

That the critics of "media imperialism" typically failed to call into question commercialisation at this level was concordant with the beginning of a new historical conjuncture in 1989, in which it was increasingly felt that there was no longer any meaningful alternative to liberal capitalism. Thus, the end of the Cold War deeply affected international communication research. While it did not cause a return to modernisation theory and its belief in the superiority of Western rationality, it did lead to a temporary demise of imperialist theories and the reinstatement of liberal internationalist conceptions, this time focused on the concept of globalisation.

\section{International Communication through the Lens of Globalisation Theory}

Three interrelated themes are characteristic of research that emphasises the importance of globalisation as a theoretical category (Gilman 2003, 259-263; Ampuja 2013). First, globalisation researchers assume that nation states are becoming increasingly irrelevant and eroded by transnational political, economic and communicational forces. Second, they focus on cultural developments that open "new spaces for difference, diversity, hybridity, multiplicity, and localism" (Gilman 2003, 260). Third, they consider the transformations of geography and space to be key analytical categories. Translated into research concerning media and communications, such tendencies generate arguments that go beyond the above-discussed standard critiques of mediacultural imperialism. Cultural globalisation theorists are not content to emphasise "contra-flows" as features that go against the Western media domination over peripheral nations; instead, they want to advance a perspective that points to a more thorough cultural complexity, one that challenges the nation state-based "boundary-thinking" of traditional analyses of international communication.

Specifically because of the boundary-crossing power of electronic media, cultures today are in heightened contact with one another, which brings into being less spatially fixed and increasingly hybridised and deterritorialised cultures. This creates a "disjunctive" global cultural order "that cannot any longer be understood in terms of existing center-periphery models" 
(Appadurai 1996, 32). M edia researchers who adopt such post-structuralist conceptions of culture reason that if there are no national hierarchies (as they are imaginary constructs, because nations themselves are imaginary constructs), then there is no reason to speak of external control or media imperialism. What remains is the increasing cross-pollination of cultures in a decentred network that gives rise to new cultural imaginations and identities. Such a hopeful vision of acentric global cultural flows naturally dispels fears over cultural imperialism, which globalisation theorists generally reject as an analytic category. Tomlinson $(1991,175)$ draws a line between imperialism and globalisation by explaining that imperialism refers to a centralised, purposeful project, "the intended spread of a social system from one center of power across the globe", while "the idea of 'globalisation' suggests interconnection and interdependency of all global areas, which happens in a far less purposeful way".

Globalisation theorists claim that the era of geopolitical competition and imperialism is coming to an end and is being replaced by cultural cosmopolitanism and the strengthening of systems of post-national global governance. In addition to the work of many cultural globalisation researchers, this ethos is also apparent in the influential work of M anuel Castells. Thus, while he noted "the return of the state" due to the Bush Administration's unilateral war on terror following $9 / 11$, he saw this merely as "the last imperial hurrah" of "the last would-be-sovereign state", whose actions ran counter to a "historical logic" pointing towards increasing global interdependence (Castells 2004, 344-355). With this he refers to the coming of the global network society that reduces the power of nation states and subjects them to the decentralising power of information technological networks and flows. In media studies proper, such an approach is welcomed by the advocates of the new integrative paradigm of mediatisation, such as Hepp and Couldry (2009). Echoing many globalisation sociologists' critiques of nation state-centred "container thinking", they argue that we live "in an era of media flows that consistently overlap national borders", and that this necessitates a turn to a novel approach in the study of media cultures that "is 'transnational' not 'international'" (ibid., 32, 43).

The call to move from international towards transnational or global communication research is not without its ironies: such calls emerged at a time when the combination of forces that created the current of globalisation had already began to unravel. In retrospect, the huge academic interest in globalisation was "a conjunctural phenomenon of the 1990s" (Rosenberg 2005 , 4). The collapse of the Soviet Union and the sudden ending of the Cold War generated "an enormous sense of temporal acceleration and spatial compression" (ibid., 6) and prompted the idea that now, finally, the fetters of transnational forces of all kinds had been removed. Assisted by the latest communication technologies in particular, these forces would integrate the globe in previously unseen ways. Many of the forces to which globalisation theorists pointed were real, but they mistook the conjunctural combination of events around the end of the Cold War for epochal or structural transformations, out of which a wholly new form of global society would emerge. However, since the turn of the millennium, the transnational ethos of globalisation theory has gradually lost its momentum in the face of vigorous re-assertions of national interest on the part of major states (ibid., 3).

It seems that media researchers who insist on upholding the central tenets of globalisation theory manage to do so only by myopically emphasising one dimension of this theory, namely, the technological capacity of new means of communication to bypass nationalterritorial frameworks. However, there is no reason to make epochal declarations concerning the need to move our sphere of interest from a national to a transnational plane. To do so is to forget that, rather than representing "two opposing forces that threaten to split modernity apart", transnational-cosmopolitan networks and flows have "co-emerged and co-evolved" with 
manifestations of nationalism and nation state power throughout the modern period (Chernilo 2006, 16), albeit with differing intensities at different times and in different contexts.

Nonetheless, media researchers who have studied international communication through the lens of globalisation theory have typically identified the nation state as the main force standing in the way of human emancipation, against which they have positively contrasted the assumed capacity of global media technologies to promote cosmopolitan interactions and cultural hybridisations. A critical focus towards the state as a national entity is, of course, perfectly warranted and has increasing significance today in light of the rise of different xenophobic nationalisms. Yet, one should not set up "a false dichotomy of global good and national bad" (or vice versa), since "it is not spaces in themselves, be they national, local or global, that are intrinsically progressive or reactionary, but the social relations and politics within and between such spaces" (Kiely 2005, 30).

This is worth pointing out since the cultural globalisation theorists have tended to promote negative freedoms, especially the right to exercise individual autonomy from the nation state, while showing a "reluctance to engage critically with economic power" (Curran 2002, 174). They have not paid proper critical attention to the transnational capitalist system, including its corporate-ideological forms and the increasing commodification of social and cultural life (Jameson 1998, 74). These features are connected to class structures and increasing material inequalities, both nationally and globally, which set definite limits on individuals' and collectives' capacities to realise the promises of increasing mobility and openness to new cosmopolitan identities envisioned by cultural globalisation theorists. Broadly accepting that capitalism is the only game in town after the end of the Cold War, they prefer not to seek emancipatory perspectives in critiques of imperialism or capitalism but in the new sources of post-national imagination provided by new media and communications. The problem here is that such progressive goals are decoupled from a structural critique of capitalism and its contemporary neoliberal form that has generated "ubiquitous economic insecurity and inequality, polarisation between surplus and deficit nations, asset bubbles and generalised financial volatility, and the inevitable 'populist' (often nationalist) illiberal blowback" (Dale 2017).

By overlooking such realities, globalisation theory and the kind of international communication research that it inspires do not take enough distance from liberal internationalist views, in which even the increasingly commercialised and privatised media can be represented as forces of cultural diversity and decentralisation. While globalisation theory is very different from modernisation theory, especially in terms of its healthy suspicion of Western cultural superiority, they are both compatible with liberal capitalism and its hegemonic legitimation. Considering this, it is no wonder that the neoliberal expansion of market power throughout the world has resulted in calls to positively reassess the notion of media-cultural imperialism (e.g., M irrlees 2013; BoydBarrett 2015).

\section{From Globalisation to New (M edia) Imperialism}

Today, we live in a historical conjuncture that significantly differs from the globalisation zeitgeist of the 1990s and early 2000s, especially with regard to the renewal of geopolitical conflicts between competing capitalist states, such as those in Syria and Ukraine. These crises have prompted talks about a "new Cold War", which typically rest on the mainstream Western interpretation, according to which the original Cold War was a bipolar contest between two military-ideological powers, with the Soviet Union being the main aggressor and the US being the defender of "the free world". For example, Russia's annexation of Crimea in 2014 is, in this 
frame, taken as a sign of a return to a grand East-West conflict. Such geopolitical tensions are real, but the "new Cold War", as an analytical concept, is an overgeneralisation that "obscures more than it reveals" (Westad 2018).

The current world order is more complex than the concept of a new Cold War allows. China, for instance, which has become either the largest or the second largest economy in the world depending on which statistics one uses and the main consumer of energy, has global ambitions, while other BRICS countries (e.g., Russia and India) are more interested in securing their status as regional hegemons (Kiely 2015, 167). Despite the rise of China, the United States remains the world's economic and financial centre, orchestrating "a network of international alliances that bind the advanced capitalist states to its political and military leadership" (Callinicos 2014). However, the United States' Cold War status as the "shining city upon a hill" for the global capitalist system as a whole has eroded. Furthermore, the global financial crisis and the neoliberal forces to which it is tied to have de-legitimised Western democratic capitalism in general, exemplified by rising socio-economic inequality, the unpopularity of neoliberal austerity and structural reform policies, the retreat of political decision making power to international market institutions, the Brexit vote and Donald Trump's victory in the US presidential elections.

The return of major geopolitical tensions and the crisis of liberal-democratic capitalism in the early decades of the 2000s have undermined the analytical relevance of liberal notions of globalisation. In much the same way that modernisation theory was challenged by theories of imperialism in the 1960s and 1970s, a return to theories of imperialism is needed today as a critical response to the inadequacies of globalisation theory-inspired international communication research.

However, theories of imperialism can take many directions, all of which are not of equal value for an analysis of contemporary capitalism and international communication. On the one hand, both the "ultra-imperialist" theory of capitalist integration by Karl Kautsky, as well as Michael Hardt and Antonio Negri's theory of "Empire", which emphasise a new and more peacefully integrated global capitalist order, do not register the constant redistributions of power between the leading capitalist states or the unevenness of capitalist development that create conflicts between rival powers. On the other hand, considering the concept of imperialism, as Sparks (2012, 289-290) does, only in the context of the actions of "competing, large [and] developed states" and leaving out "private economic activities" is too restricting. First, this approach ignores the universalisation of capitalist imperatives through the actions of both states and capital (Wood 2012). Nation states with strong military capacities (the US in particular) have been important for the forceful opening up of markets to capital accumulation, but this has also been advanced by global economic institutions and corporations, which have imposed market imperatives and neoliberal practices throughout the world (Harvey 2004, 70). Second, a view of imperialism that focuses only on states ignores the various dimensions of capitalist imperialism that were already identified by Lenin in a period when capitalism had not yet been universalised. Thus, in addition to pointing to the territorial division of the world among capitalist powers, Lenin also pointed to what are now called major transnational corporations, which share the world markets among themselves (Fuchs 2010, 34-35).

Due to such variance, a comprehensive theory of imperialism must focus on the dialectical co-existence of "capitalist" (economic) and "territorialist" (geopolitical) imperialism. These constitute two logics of "new imperialism" that "are tightly interwoven", yet "in no way reducible to each other" (Harvey 2003, 183). Accordingly, while recent decades have witnessed extensive capitalist imperialism, that is, the introduction of neoliberal political measures that have served transnational class interests, this has not ended geopolitical competition. The relationships 
between these two dimensions are often contradictory. Due to the clashing geopolitical interests of various nation state powers, "appeals to universal principles coexist in complex ways with assertions of national interest" (Callinicos 2002, 262), such as the Davos meetings with global elites on the one hand and the attempts made by Russia to demonstrate its national strength on the other.

Having outlined a neo-M arxist perspective on "new imperialism", according to which imperialism refers to the intersection of economic and geopolitical competition, the question of how this should be connected to the study of international or global communication arises. Current ideas concerning media imperialism need to be developed in ways that consider the above-discussed dual dynamics of new imperialism, which requires going beyond a narrow understanding of media imperialism. In this regard, Boyd-Barrett $(2015,11-14)$ usefully makes a distinction between media as imperialists and media for imperialism. When combined with the two logics of new imperialism, this provides us with three types of connections between media and imperialism.

First, there is the concentrated power of media conglomerates that "can be regarded as agents of imperialism when they exercise business practices [...] that suppress the viability of media in countries other than their own" (Boyd-Barrett 2015, 14). When the imperial power of media corporations and information industries is assessed at this level, it is evident that they are not as economically powerful as the finance or fossil fuel industries (Fuchs 2010). However, while not dominant, they are nevertheless still important, as seen through the domination of the Internet and social media - and thus the digital infrastructures with which people interact across the world - by a handful of mainly US platform companies ( $\mathrm{in} 2013$ ).

Secondly, the media are agents for imperialism. This occurs in two ways. 1) The media advance capitalist imperialism by acting as the "missionaries of global capitalism" (Herman \& McChesney 1997). In the post-Cold War period, globally, media systems have become more commercialised and increasingly owned by private media industries. Serving the advertisers and consumers instead of citizens, they promote consumer-oriented lifestyles and business-friendly entertainment (ibid., 152ff). Because these commercialised media systems are themselves an integral part of the global capitalist economy, they tend to align politically with corporate interests and give preference to hegemonic neoliberal discourses that advertise privatisation, austerity, financialisation, entrepreneurialism and market-based solutions in general as good for society. At this level, cultural standardisation exists: by prioritising advertisers' interests and neoliberal ideology, private media corporations promote a one-dimensional view of what constitutes the common good. Focusing on media as transnational agents for capitalist imperialism helps us move past the historically frozen idea that media imperialism concerns US cultural domination and little else. Referring to studies that criticise media-cultural imperialist theories on the basis of contraflows or local audiences' varying interpretations of Western media products, M cChesney and Herman $(1997,152)$ note that the critics missed the point of political economic theories of media imperialism, which is the implantation of the commercial model, not its national character.

Technological changes must also be included in new conceptions of media imperialism. Today, one increasingly important aspect of capitalist imperialism in the mediacultural sphere is the commodified nature of everyday online practises. When people use smartphones or the Internet, they are not only targeted as consumers but also become commodified as "prosumers", whose usage data is sold to advertisers (Fuchs 2014, 106). This occurs in a digital environment that is privately regulated by platform companies' technologies and software, whereby "it is not simply code but, increasingly, capital that regulates" (D. Freedman 2012, 115). In addition, capitalist imperialism today is advanced through the increasing 
regulation of the production of information, knowledge and culture by cultural and intellectual property rights agreements that represent "the commodification of culture as accumulation by dispossession" (Hesmondhalgh 2008, 105-107).

2) When assessing the media as agents for geopolitical imperialism, we are dealing with media activities in the context of conflictual international relations. The media work for geopolitical powers "when they prioritise the voices, justifications and discourses of imperial actors over the voices of victims, dissidents and alternatives, and when they omit or marginalise details and perspectives that would serve to critique imperial power" (Boyd-Barrett 2015, 14). As a recent example of this, Boyd-Barrett (2018) discusses the one-sided representation of the Ukraine crisis in the Western mainstream media, which has failed to provide proper context and which has downplayed US attempts to influence the Ukrainian elections and the Washington-led neoliberal effort to open the country to international corporations and finance to the exclusion of Russia's economic interests. Media imperialism is exercised by the media of many different nation states, not only by the US (Boyd-Barrett 2015, 9), and thus the Ukrainian crisis also involves pro-Russian media propaganda that seeks to justify Russia's imperial actions near its borders. Nevertheless, biased perceptions regarding US geopolitical interests have been dominant, particularly in Western news media, and there is little evidence of the BRICS countries' countervailing media power in this regard (Boyd-Barrett 2018, 2).

The concepts of imperialism and media imperialism are still needed, because they direct attention to processes that theories of globalisation or mediatisation (see e.g., M urdock 2017) are ill-equipped to deal with, namely, the unevenness of global capitalist development and its current neoliberal nature. However, a return to theories of imperialism in the early twenty-first century should not be accomplished via an unreflective recirculation of media imperialism arguments developed during the twentieth century. Research concerning media imperialism must recognise the constantly shifting balance of power between capitalist states. The economic rise of China and the "soft power" efforts of its government show that previous theories of underdevelopment do not function, at least without important qualifications, in the contemporary context, because they fail to account for the willingness and capacity of former peripheral nations to become core players in the global capitalist system, rather than developing themselves outside of it. Similarly, a contemporary theory of media imperialism should not focus on the still-dominant status of the United States in international communication from a position that decries "Americanisation", but it should rather shed light on its key role as the administrator of the expansion of capitalist economic imperatives across the world. Theories of new imperialism are sensitive to such realities and provide a fruitful foundation for the further development of media imperialism approaches in the contemporary context.

\section{References}

Alleyne, Mark D. 1995. International Power and International Communication. Houndmills: MacMillan.

Ampuja, Marko. 2013. Theorizing Globalization. A Critique of the M ediatization of Social Theory. Chicago, IL: Haymarket Books.

Appadurai, Arjun. 1996. M odernity at Large: Cultural Dimensions of Globalization. Minneapolis: University of M innesota Press.

Baran, Paul A. 1957. The Political Economy of Growth. New York: M onthly Review Press. 
Bellamy Foster, John. 2007. "The Imperialist World System. Paul Baran's Political Economy of Growth Fifty Years After." M onthly Review 59 (1). https://monthlyreview.org/2007/05/01/theimperialist-world-system/

Boyd-Barrett, Oliver. 1977. "M edia imperialism: towards an international framework for the analysis of media systems." In J. Curran, M. Gurevitch and J. Woollacott (eds.), Mass

Communications and Society. London: Arnold, 116-135.

Boyd-Barrett, Oliver. 2015. M edia Imperialism. London: Sage.

Boyd-Barrett, Oliver. 2018. Western M ainstream M edia and the Ukraine Crisis. A Study in Conflict Propaganda. London and New York: Routledge.

Callinicos, Alex. 2002. "M arxism and global governance." In D. Held and A. M cGrew (eds.), Governing Globalization. Power, Authority and Global Governance. Cambridge: Polity Press, 249266.

Callinicos, Alex. 2014. "The Multiple Crisis of Imperialism." International Socialism, issue 144 (October 10, 2014). http:// isj.org.uk/ the-multiple-crises-of-imperialism/

Castells, M anuel. 2004. The Information Age: Economy Society and Culture. Volume II: The Power of Identity. Second Edition. Oxford: Blackwell.

Chadha, Kalyani, and Kavoori, Anandam. 2000. "M edia imperialism revisited: some findings from the Asian case." M edia, Culture \& Society 22 (4): 415-432.

Chadha, Kalyani, and Kavoori, Anandam. 2015. "The New Normal. From M edia Imperialism to Market Liberation - Asia's Shifting Television Landscape." M edia, Culture \& Society 37 (3): 479-

492.

Chernilo, Daniel. 2006. "Social Theory's M ethodological Nationalism. M yth and Reality." European Journal of Social Theory 9 (1): 5-22.

Chomsky, Noam. 1992. Deterring Democracy. New York: Hill and Wang.

Cmiel, Kenneth. 1996. "On Cynicism, Evil, and the Discovery of Communication in the 1940s.

Journal of Communication." 46 (3): 88-107.

Curran, James. 2002. M edia and Power. London: Routledge.

Dale, Gareth. 2017. "Leaving the Fortresses: Between Class Internationalism and Nativist Social Democracy." Viewpoint Magazine, November 30, 2017.

https:// www.view pointmag.com/2017/11/30/leaving-fortress-class-internationalism-nativist-

social-democracy/

Frank, Andre Gunder. 1969. Capitalism and Underdevelopment in Latin America. Historical Studies of Chile and Brazil. New York: Monthly Review Press.

Freedman, Des. 2012. "Outsourcing internet regulation." In J. Curran, N. Fenton and D. Freedman (eds.), M isunderstanding the Internet. London: Routledge, 95-120.

Freedman, Lawrence. 2018. "Putin's New Cold War." New Statesman, 14 March, 2018.

https://www.newstatesman.com/politics/uk/2018/03/putin-s-new-cold-war

Fuchs, Christian. 2010. "New imperialism. Information and Media Imperialism?" Global M edia and Communication 6 (1): 33-60.

Fuchs, Christian. 2014. Social Media. A Critical Introduction. London: Sage.

Fukuyama, Francis. 1992. The End of History and the Last M an. New York, NY: The Free Press.

Gilman, Nils. 2003. M andarins of the Future. M odernization Theory in Cold War America. Baltimore and London: The Johns Hopkins University Press.

Hardt, M ichael and Negri, Antonio. 2000. Empire. Cambridge, M A: Harvard University Press.

Harvey, David. 2003. The New Imperialism. Oxford, Oxford University Press.

Harvey, David. 2004. "The New Imperialism: Accumulation by Dispossession." Socialist Register vol. 40: 63-87. 
Held, David. 2002. "Cosmopolitanism: Ideas, Realities and Deficits." In D. Held and A. M cGrew (eds.), Governing Globalization. Power, Authority and Global Governance. Cambridge: Polity Press, 305-324.

Hepp, Andreas and Couldry, Nick. 2009. "What Should Comparative Media Research be Comparing? Towards a Transcultural Approach to 'M edia Cultures'." In D. Thussu (ed.) Internationalizing M edia Studies. Abingdon: Routledge, 32-47. Herman, Edward S. and M cChesney, Robert W. 1997. The Global M edia. The New Missionaries of Global Capitalism. London: Cassell.

Hesmondhalgh, David. 2008. "Neoliberalism, imperialism and the media." In D. Hesmondhalgh and J. Toynbee (eds.), The M edia and Social Theory. Abingdon: Routledge, 95-111. Jameson, Fredric. 1998. "Notes on globalization as a philosophical issue." In F. Jameson and M. M iyoshi (eds.), The Cultures of Globalization. Durham: Duke University Press, 54-77.

Jin, Dal Yong. 2013. "The Construction of Platform Imperialism in the Globalization Era." TripleC 11 (1): 145-172.

Kiely, Ray. 2005. Empire in the Age of Globalisation. US Hegemony and Neoliberal Disorder. London: Pluto Press.

Kiely, Ray. 2015. The BRICs, US 'Decline' and Global Transformations. Houndmills: Palgrave MacM illan.

Klare, M ichael T. 2018. "The New Cold War is Here - and now 3 M ajor Powers are Involved." The Nation, March 3, 2018. https:// www.thenation.com/article/the-new-cold-war-is-here-and-nowthree-major-powers-are-involved/

Latham, M ichael. 2000. M odernization as Ideology: American Social Science and "Nation Building" in the Kennedy Era. Chapel Hill: University of North Carolina Press.

Lerner, Daniel. 1958. The Passing of Traditional Society: M odernizing the M iddle East. New York: Free Press.

Lerner, Daniel. 1969. "M anaging Communication for M odernization: A Developmental Construct." In A. A. Rogow (ed.), Politics, Personality, and Social Science in the Twentieth Century: Essays in Honor of Harold D. Lasswell. Chicago: The University of Chicago Press, 171-196.

Mair, Peter. 2013. Ruling the Void. The Hollowing of Western Democracy. London: Verso. M irrlees, Tanner. 2013. Global Entertainment M edia: Between Cultural Imperialism and Cultural Globalization. New York: Routledge.

Murdock, Graham. 2017. "M ediatisation and the Transformation of Capitalism: The Elephant in the Room." Javnost - The Public 24 (2): 119-135.

Nordenstreng, Kaarle, and Varis, Tapio. 1974. Television Traffic: A One-Way Street? A Survey and Analysis of the International Flow of Television Programme Material. Reports and Papers on Mass Communication no. 70. Paris: UNESCO.

Popp, Roland. 2008. "An Application of M odernization Theory during The Cold War? The Case of Pahlavi Iran." The International History Review 30 (1): 76-98.

Preston, William Jr. 1989. "The History of U.S.-UNESCO Relations." In W. Preston, Jr., E. S. Herman \& H. I. Schiller (eds.), Hope \& Folly. The United States and UNESCO 1945-1985. M inneapolis: University of M innesota Press, 3-202.

Rosenberg, Justin. 2005. Globalization theory: a post mortem. International Politics 42 (1), 2-74. Said, Edward. 1994. Culture and Imperialism. London: Vintage.

Schiller, Herbert I. 1969. M ass Communications and American Empire. Boston: Beacon Press. Schiller, Herbert I. 1976. Communication and Cultural Domination. New York: M .E. Sharpe. Schiller, Herbert I. 1991. "Not Yet the Post-Imperialist Era." Critical Studies in M ass Communication 8 (1): 13-28. 
Schiller, Herbert I. 2000. Living in the Number One Country. Reflections from a Critic of American Empire. New York: Seven Stories Press.

Simpson, Christopher. 1994. Science of Coercion: Communication Research and Psychological Warfare, 1945-1960. Oxford: Oxford University Press.

Sinclair, John, Jacka, Elisabeth, and Cunningham, Stuart. 1996. Peripheral Vision. In J. Sinclair, E. Jacka and S. Cunningham (eds.), New Patterns in Global Television. Peripheral Vision. Oxford: Oxford University Press, 1-32.

Sparks, Colin. 2007. Globalization, Development, and the Mass M edia. London: Sage. Sparks, Colin. 2012. "Media and Cultural Imperialism Reconsidered." Chinese Journal of Communication 5 (3): 281-299.

Tomlinson, John. 1991. Cultural Imperialism: A Critical Introduction. London: Pinter Publishers. Weeks, John. 2012. "Dependency Theory." In B. Fine and A. Saad-Filho, The Elgar Companion to Marxist Economics. Cheltenham: Edward Elgar, 96-101.

Westad, Odd Arne. 2018. "Has a New Cold War Really Begun?" Foreign Affairs, March 27, 2018. https:// www.foreignaffairs.com/articles/china/2018-03-27/has-new-cold-war-really-begun Wood, Ellen M eiksins. 2012. The Ellen M eiksins Wood Reader. (Ed. by Larry Patriquin.) Leiden \& Boston: Brill. 